\title{
INTELLECTUAL CAPITAL MANAGEMENT \\ UNTUK REVITALISASI IMPLEMENTASI E-GOVERNMENT DI INDONESIA
}

\author{
Noor Azida Batubara \\ STAI Haji Agus Salim Cikarang Bekasi \\ Email: azidanoor_batubara@yahoo.com
}

\begin{abstract}
ABSTRAK
Tujuan penelitian ini adalah untuk mengidentifikasi faktor-faktor yang berpengaruh terhadap implementasi e-government di Indonesia menggunakan perspektif Intellectual Capital Management. Rendahnya peringkat implementasi e-government Indonesia berdasarkan data yang dirilis oleh PBB, secara internal kelembagaan, disebabkan masih minimnya pengetahuan SDM terhadap e-government. Adapun secara eksternal kelembagaan disebabkan rendahnya kesadaran masyarakat terhadap pentingnya melek e-literacy, dan faktor-faktor lainnya yang mempengaruhi kualitas implementasi e-government di Indonesia. Diperlukan sebuah sistem manajemen yang dapat mendongkrak terimpelemntasikannya $e$ government dengan lebih baik. Menggunakan metode penelitian dengan pendekatan kualitatif deskriptif, data-data yang mendukung penelitian diperoleh melalui studi literatur kepustakaan yang bersumber dari buku-buku yang relevan, jurnal ilmiah, artikel-artikel ilmiah, dan internet yang relevan dengan penerapan Intellectual Capital Management guna menghasilkan informasi yang mendalam dan komprehensif mengenai permasalahan terkait. Hasil penelitian menunjukkan ICM dengan ketiga elemennya yang saling bersinergi melalui pengetahuan (human capital, structural capital, dan relational capital) merupakan konsep manajemen lembaga dengan proyeksi penciptaan nilai melalui pengetahuan dan inovasi yang dimilikinya dapat meningkatkan kualitas e-government yang unggul dan inovatif yang berkontribusi positif bagi bangsa dan negara Indonesia.
\end{abstract}

Kata Kunci : Revitalisasi e-government, Inovasi Berkelanjutan, Intellectual Capital, Intellectual Capital Management.

\section{ABSTRACT}

The purpose of this research is to identify the factors influencing implementation of e-government in Indonesia, using the perspective of Intellectual Capital Management. The low ranking of Indonesia's egovernment implementation based on data released by the United Nations, is internally institutional, due to the lack of human resources knowledge of e-government. While, externally institutional factor is caused by low public awareness of the importance of e-literacy, and other factors that affect the quality of egovernment implementation in Indonesia. A management system is needed that can boost e-government implementation better. Methodology of this research is used a descriptive qualitative approach, data that support research is obtained through the study of literature sourced from relevant books, scientific journals, scientific articles, and the internet that are relevant to the application of Intellectual Capital Management in order to produce in-depth and comprehensive information, regarding related issues. The result of research showed, that three capitals of ICM that they enggage and support each other in knowledge eternally (human capital, structural capital, and relational capital) is a concept of institutional management with its projected value creation, through knowledge and innovation. It can to increase quality of superior and innovative e-government that contributes to the nation and state of Indonesia positively.

Keywords: E-government Revitalization, Sustainable Innovation, Intellectual Capital, Intellectual Capital Management.

\section{PENDAHULUAN}

Sejak tercetusnya era masyarakat informasi, berbagai informasi dapat diperoleh dengan leluasa. Didukung dengan teknologi informasi yang semakin berkembang pesat dan dinamis, memberikan ruang gerak yang luas untuk melakukan lompatan demi lompatan perubahan yang signifikan dengan satu tujuan memudahkan masyarakat dalam memperoleh pengetahuan yang diperlukan. Demikian halnya di Kementerian/ lembaga negara, Instruksi Presiden RI Nomor 3 Tahun 2003 tentang Kebijakan dan Strategi Nasional Pengembangan E-government sistem pelayanan publik mengalami transformasi dari 
traditional government ke digital government atau yang dikenal dengan e-government.

Transformasi bentuk pelayanan publik berbasis internet ini, merupakan bentuk adaptasi pemerintah dengan kemajuan teknologi informasi sebagai manifestasi dari perkembangan pengetahuan. E-government sebagai situs resmi pemerintah, selayaknya harus sudah memiliki sistem pelayanan yang sejalan dengan kemajuan teknologi informasi. Karena, survive-nya sebuah institusi/lembaga bergantung pada kemampuannya beradaptasi dengan perkembangan zaman (Geus, 1997). Dan, implementasi e-government merupakan upaya pemerintah Indonesia untuk tetap survive dan menghindari digital divide di era masyarakat informasi. Oleh karena itu diperlukan kemampuan lembaga melakukan improvisasi inovasi yang sesuai "the way the world works" sehingga dapat beradaptasi dengan berbagai perubahan yang terjadi di era masyarakat informasi(Christensen, 1997).

Meskipun Indonesia telah mengadopsi $e$ government sejak 2003, fakta menunjukkan bahwa implementasi e-government di Indonesia masih berada di peringkat bawah. Berdasarkan peringkat E-government Development Index (EDGI) tahun 2018 yang dikeluarkan oleh Perserikatan BangsaBangsa, Indonesia berada di peringkat ke 107 dari 193 negara. Berdasarkan data yang dirilis publicadministration.un.org ini, dapat dilihat bahwa peringkat Indonesia pun ternyata masih berada di bawah negara-negara ASEAN.

Rendahnya tingkat implementasi $e$ government di Indonesia dapat diindikasikan dari beberapa aspek, seperti penggunaan website di lingkup lembaga pemerintahan yang sudah memasuki level pemanfaatan (level 4) ternyata hanya mampu diisi oleh 4 daerah dari 548 pemerintah daerah yang ada di Indonesia. Klasifikasi status terbesar berada pada level pematangan (level 2) sebanyak 341 (Yunita \& Aprianto, 2018). Aplikasi halaman website lembaga pemerintah masih banyak yang memuat layanan yang tidak terlalu informatif dan sesuai dengan yang dibutuhkan oleh masyarakat (Munandar, Pratama, \& Satria, 2017).

Minimnya pengetahuan sumber daya manusia (SDM) terkait e-government baik secara kuantitas maupun kualitas menjadi faktor yang melatarbelakangi belum efektifnya implementasi $e$ government. Demikian halnya dengan kesadaran dan kepedulian masyarakat sebagai pengguna layanan masih berada pada level rendah (Yohana \& Yazid, 2014). Belum terbentuknya payung hukum/kebijakan yang secara khusus mengatur implementasi e-government dibeberapa wilayah berpengaruh dominan terhadap implementasi $e$ government(Nugraha, 2018).

Aspek lainnya yang menjadi pemicu rendahnya implementasi e-government di Indonesia perspektif dimensi Pemeringkatan e-government Indonesia (PeGI) (Masyhur, 2017) yakni: 1. Penelitian yang bersifat pengembangan e-government dan berkontribusi signifikan dalam menciptakan formulasi implementasi e-government bermutu, masih minim secara kuantitas maupun kualitas; 2 . Pengetahuan SDM tentang e-government (menguasai bidang TIK) yang minim disebabkan faktor umur, pendidikan, dan pengalaman kerja. 3 . Budaya berbagi belum ada dimana kultur berbagi (sharing) informasi belum terbiasa; 4. Budaya mendokumentasi (kodifikasi pengetahuan) juga belum lazim; 5. Belum maksimalnya dukungan pemerintah berupa kebijakan yang menguatkan impelementasi e-government; 6. Hubungan relasional berbentuk kolaborasi antara lembaga pemerintah dengan lembaga-lembaga terkait dalam mengidentifikasi kebutuhan kajian $e$ government masih sangat rendah. Hasil penelitian yang merupakan gugus dari 105 artikel penelitian di Indonesia yang dirilis oleh PeGI tersebut juga menunjukkan bahwa terkait pemenuhan kebutuhan infrastruktur, bukanlah hal yang signifikan sebagai faktor penghambat implementasi $e$ government bermutu.

Berdasarkan uraian di atas, diperlukan upaya mengelola aset intangible lembaga pemerintahan penyelenggara e-government (LPPEG) yang selama ini terabaikan dari perhitungan sebagai aset yang berpengaruh terhadap suksesnya penyelenggaraan e-government. Aset organisasi atau yang dikenal dengan istilah intellectual capital (IC) tersebut terdiri dari tiga komponen yang saling berintegrasi untuk menciptakan nilai organisasi yaitu: 1. Human capital (sumber daya manusia); 2. Structural capital (organisasi); 3. Relational capital (relasi/hubungan).

Mengelola IC merupakan proses menanamkan pemahaman dan pengetahuan e-literacy (melek e-literacy) kepada SDM LPPEG dan pihak yang berkepentingan, agar mereka dapat berpartisipasi secara positif dan bertanggungjawab dalam penyelenggaraan e-government untuk saat ini dan yang akan datang.

Penelitian ini bertujuan mengeksplorasi kinerja --berbasis pengetahuan-- LPPEG melalui aktivasi IC secara maksimal dalam upaya revitalisasi implementasi e-government ke arah yang lebih baik. Sebab, pada dasarnya kemajuan sektor pembangunan di semua bidang 
dikendalikan oleh pengetahuan dan informasi (Akpinar \& Akdemir, 2011). Hal tersebut yang menjadi titik perhatian penelitian ini, sehingga upaya revitalisasi implementasi e-government berjalan sukses. Sejauh ini, penelitian mengenai IC yang diterapkan dalam bidang layanan publik $e$ government di Indonesia belum ada yang melakukan, sehingga diharapkan penelitian ini dapat menjadi solusi secara konseptual bagi perkembangan e-government dan tingkat melek warga negara terhadap teknologi elektronik dan berpengaruh pada partisipasi implementasi $e$ government.

\section{LITERATURE REVIEW \\ E-Government: Merefleksikan Pelayanan Publik Berbasis Pengetahuan}

E-government didefinisikan sebagai upaya pemanfaatan dan pendayagunaan telematika untuk meningkatkan efisiensi dan cost-effective pemerintahan, memberikan berbagai jasa pelayanan kepada masyarakat secara lebih baik, menyediakan akses informasi kepada publik secara lebih luas, dan menjadikan penyelenggaraan pemerintahan lebih bertanggung jawab (accountable) serta transparan kepada masyarakat (Satriya, 2006). Guah (2007) mendefinisikan e-government sebagai sebuah sistem yang membantu pemerintah secara kelembagaan dalam memproses informasi, membangun pelayanan yang sehat, inovatif dalam pelayanan, dan pengelolaan pengetahuan organisasi yang berkelanjutan sehingga menciptakan pengetahuan baru yang mendukung terhadap penyelenggaraan pemerintah yang baik.

Berdasarkan beberapa definisi di atas, egovernment mengacu kepada birokrasi, relasi antara stakeholder dan mitra, menggunakan sumber daya untuk efek maksimum, pengetahuan, kemampuan, inovasi, dan kebijakan-kebijakan terkait pelayanan publik sehingga dapat diselenggarakan secara efektif dan efisien.

Jenis layanan publik tersebut, sebagaimana disebutkan dalam Undang-Undang (UU) Nomor 25 Tahun 2009 Pasal 5 ayat 1 dan 2 meliputi pelayanan barang publik dan jasa publik serta pelayanan administratif meliputi pendidikan, pengajaran, pekerjaan dan usaha, tempat tinggal, komunikasi dan informasi, lingkungan hidup, kesehatan, jaminan sosial, energi, perbankan, perhubungan, sumber daya alam, pariwisata, dan sektor strategis lainnya.

Memaksimalkan pengimplementasian egovernment melalui perencanaan, dedikasi sumber daya, dan kemauan politik yang berkelanjutan (political will) (World Bank, 2002) akan menciptakan nilai (value) bagi lembaga pemerintahan penyelenggara e-government (Satriya, 2006). Nilai yang menjadi daya tarik bagi stakeholder dan mitra lembaga untuk membangun kerjasama serta dapat menguatkan eksistensi lembaga pemerintah mengembangkan penyelenggaraan birokrasi pemerintah yang berbasis elektronik dalam rangka meningkatkan kualitas layanan publik yang transparan dan akuntabel.

Komponen e-government terdiri dari: 1. Kepemimpinan Eksekutif(Executive Leadership); 2. Keikutsertaan Otoritas Legislatif dan Otoritas lain berdasarkan Yurisdiksi (Wakil lembaga legislatif); 3. Penasehat Teknologi Informasi (IT Advisor); 4. Pengelola pada tingkat lembaga/ organisasi (Enterprise Level Governance Boards); 5. Pengawas dan pengendali teknis (Technical Oversight Boards)

Pemerintah membutuhkan langkah-langkah yang tepat untuk memaksimalkan impelementasi e-government yang berkualitas terkait kebijakan dalam pengelolaan e-government di lingkungan pemerintahan guna memfasilitasi kebutuhan masyarakat. Memastikan bahwa layanan publik yang diberikan sesuai dengan kepuasan pengguna.

\section{Intellectual Capital}

Intellectual capital (IC) didefinisikan sebagai kombinasi dari sumber daya intangible dan kegiatan-kegiatan yang melegitimasi lembaga mentransformasi sebuah bundelan material, keuangan, dan sumberdaya manusia dengan tersistematis untuk menciptakan nilai dihadapan para pemangku kepentingan (stakeholder value) (Europian Commision, 2000). Dengan demikian konsep yang dikembangkan oleh IC ialah menciptakan keunggulan kompetitif yang diperoleh melalui inovasi-inovasi kreatif yang dihasilkan melalui intangible assets milik lembaga dengan berbasis pada pengetahuan.

Istilah lain dari IC yang digunakan dalam berbagai literatur antara lain intangible assets (literatur akuntansi), knowledge assets (ekonomi), intellectual capital (literatur manajemen dan hukum), dan intellectual property (berkaitan dengan hak paten, hak cipta, merek dagang) (Lev, 2001).

Fakta menunjukkan bahwa IC lembaga merupakan penggerak dalam meningkatkan penciptaan nilai kompetitif perusahaan yang modern dibanding sumber daya fisik dan finansial (Petty \& et al, 2009). Contoh intangible assets ialah hak cipta (copyrights), hak paten (patents), hak merek dagang (trademarks), goodwill, program komputer (computer programs), lisensi 
(licenses), waralaba (franchises), biaya organisasi (organization costs), izin eksplorasi (exploration permits), izin ekspor-impor (import and export permits), dan kapitalisasi biaya iklan (Fredman, 2000).

\section{Taksonomi Intellectual Capital}

Secara umum pengklasifikasian IC yang berlaku di lembaga merujuk pada taksonomi yang diusulkan oleh Saint Onge (1996), Sveiby (1997), Stewart (1997), Bontis (1998), dan Roos et.al (1998), yang membagi taksonomi IC dalam tiga klasifikasi yang sama yaitu human capital (HC), structural capital (SC) dan relational capital (RC) (Tseng \& Goo, 2005).

Human capital (HC) didefinisikan sebagai kumpulan kapabilitas pegawai yang terdiri dari kompetensi (competence), sikap (attitude), dan kecerdasan intelektual (intellectual agility) (Roos, Roos, Dragonetti, \& Edvinsson, 1997).

Kedua, structural capital (SC) didefinisikan Bontis (2000) sebagai modal intelektual yang melekat dalam perusahaan atau organisasi mencakup perangkat keras (hardware), perangkat lunak (software), basis data (database), struktur organisasi (organizational structure), hak paten, merek dagang (trademarks), dan segala hal lain dari kemampuan organisasi yang mendukung produktivitas karyawan - yang tertinggal di kantor saat karyawan pulang(Bontis, 2000). Dengan kata lain, SC merupakan proses rutinitas lembaga dan strukturnya yang mendukung usaha SDM organisasi dalam menghasilkan intellectual performance yang optimal dan business performance secara keseluruhan.

Ketiga, relational capital $(R C)$ didefinisikan sebagai modal intelektual yang terkait hubungan antara organisasi dengan pelanggan, konsumen, perantara, perwakilan, pemasok, mitra, pemilik, kreditur, dan sejenisnya(Ross \& et al., 2001).

\section{Intellectual Capital Management}

Intellectual Capital Management (ICM) didefinisikan sebagai penyebaran dan pengelolaan sumber daya IC dan transformasi (ke dalam sumber daya intelektual lainnya atau ke sumber ekonomi tradisional) untuk memaksimalkan penciptaan nilai lembaga di hadapan stakeholder (Göran, 2005).

Stakeholder dalam suatu organisasi didefinisikan Freeman dalam Flak \& Rose (2005) adalah setiap kelompok atau individu yang dapat mempengaruhi atau dipengaruhi oleh pencapaian tujuan organisasi. Stakeholders dibagi menjadi dua kelompok (Clarkson, 1995), terdiri dari: 1.
Stakeholders primer, yakni pihak dimana tanpa keterlibatannya yang berkelanjutan organisasi tidak dapat bertahan. Terdiri dari pemegang saham, pemerintah, komunitas, pegawai, pelanggan, dan pemasok. Adapun yang memiliki pengaruh dan kepentingan dikatakan sebagai stakeholder primer dan harus dilibatkan penuh dalam tahapan-tahapan kegiatan. 2. Stakeholders sekunder, didefinisikan sebagai pihak yang mempengaruhi atau dipengaruhi oleh organisasi, tetapi mereka tidak terlibat dalam transaksi dengan organisasi dan tidak begitu penting untuk kelangsungan hidup organisasi terdiri dari media dan berbagai kelompok kepentingan tertentu. organisasi tidak bergantung pada kelompok ini untuk kelangsungan hidupnya, tapi mereka bisa mempengaruhi kinerja organisasi.

Dalam prosesnya, ICM dapat membuat lembaga lebih inovatif melalui pelaksanaan rutinitas yang meliputi identifikasi, pengembangan dan penggunaan kombinasi unik dari sumber pengetahuan untuk menciptakan nilai. ICM memberikan metodologi yang efisien untuk mengidentifikasi, mengukur, mengelola dan menyebarkan intangible asset (pengetahuan) lembaga dengan menyinergikan tiga komponen IC (HC, SC, dan RC). Interaksi kinerja fungsional IC (lihat gambar 2) mendeskripsikan setiap elemen saling bersinergi antara yang satu dengan yang lain dalam menciptakan nilai lembaga.

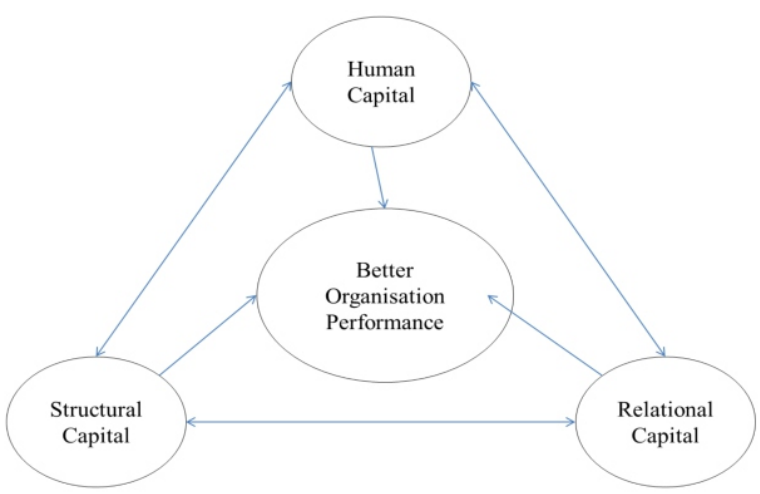

Gambar 2 Kinerja Fungsional IC (Caddy, 2007)

Interaksi tersebut menjelaskan bagaimana intangible assets di lingkungan lembaga dipengaruhi oleh tindakan dan ditransmisikan ke kinerja di lingkungan tersebut melalui proses manajemen. Adapun hasil identifikasi tersebut dapat menjadi tolak ukur kualitas IC yang dimiliki lembaga tersebut(Kelly, 2004). Dengan demikian ICM merupakan proses sekaligus struktur yang digunakan untuk melakukan dua kegiatan sekaligus yaitu penciptaan dan penggalian nilai 
lembaga melalui pemanfaatan intangible assets lembaga secara efektif.

ICM di banyak negara di Eropa, Amerika dan Asia sudah banyak diadopsi dan diimplemen- tasikan dalam berbagai sektor selain sektor ekonomi seperti di sektor swasta, komunitas pendidikan, dan pemerintah. (Yodmongkon \& Chakpitak, 2009).

Tabel 1. Implementasi ICM di Berbagai Bidang

(Hasil Penelitian Peneliti)

\begin{tabular}{|c|c|c|c|}
\hline Peneliti & Tahun & Wilayah Penelitian & Fokus Penelitian \\
\hline Dee Alwis & 2004 & $\begin{array}{l}\text { Perusahaan ConsultCo bergerak di sector } \\
\text { kesehatan dan Perusahaan ResearchCo } \\
\text { bergerak di sector R\&D (UK) }\end{array}$ & $\begin{array}{l}\text { Menciptakan nilai perusahaan melalui dava } \\
\text { inovasi perspeltif intellectual capital }\end{array}$ \\
\hline Anthony Kelly & 2004 & Sekolah-sekolah di Inggris & $\begin{array}{l}\text { Kebijakan Pemerintah terhadap sekolah } \\
\text { perspeltif intellectual capital }\end{array}$ \\
\hline Carole Bassile & 2007 & Sekolah-sekolah PPSs di Denver USA & $\begin{array}{l}\text { Manajemen intellectual capital di sekolah } \\
\text { pengembangan professional untuk } \\
\text { meningkatkann kualitas belajar siswa }\end{array}$ \\
\hline Andrew Kok & 2007 & University of Johannesburg Afrika Selatan & $\begin{array}{l}3 \text { komponen utama intellectual capital } \\
\text { management }(\mathrm{HC}, \mathrm{SC} \text {, dan } \mathrm{RC})\end{array}$ \\
\hline $\begin{array}{l}\text { Leandro Canibano } M \\
\& \text { Paloma Sanchez }\end{array}$ & 2008 & $\begin{array}{l}\text { Universitas dan lembaga penelitian di } \\
\text { Eropa }\end{array}$ & $\begin{array}{l}\text { Intellectual capital management dan } \\
\text { pelaporannya }\end{array}$ \\
\hline $\begin{array}{l}\text { Pitipong Yodmongkon, } \\
\text { \&Nopasit Chakpitak }\end{array}$ & 2009 & Komunitas Suku Mea-Hiya Thailand & $\begin{array}{l}\text { Implementasi proses intellectual capital } \\
\text { dalam mengelola pengetahuan tradisional } \\
\text { suku Mea-Hiya }\end{array}$ \\
\hline $\begin{array}{l}\text { Thyaul Ulum \& Nadva } \\
\text { Novianty }\end{array}$ & 2012 & $\begin{array}{l}\text { Perguruan Tinggi Negeri dan Swasta di } \\
\text { Indonesia }\end{array}$ & $\begin{array}{l}\text { Intellectual capital pada Office Website } \\
\text { Perguruan Tinggi }\end{array}$ \\
\hline Atefah Golshahi et. al. & 2015 & University of Sistan and Baluchestan Iran & $\begin{array}{l}\text { Kineria inovasi aspek Psikologi perspeltif } \\
\text { intellectual capital }\end{array}$ \\
\hline
\end{tabular}

Pengembangan HC dalam ICM yakni dengan mendongrak orang-orang internal lembaga sebagai aset lembaga paling berharga guna meningkatkan kinerja bisnis dan tumbuhnya keunggulan kompetitif lembaga melalui kompetensi, attitude, dan kecerdasan intelektual yang dimilikinya. Melalui ICM, HC yang berkompetensi (Gambar 3) di dalam lembaga disebut dengan Intellectual Asset (IA) sebab HC tersebut telah menjadi milik lembaga. Dan disaat IA sudah mengkonversi kompetensinya kedalam bentuk nilai, produk, pelayanan, inovasi dan brand image (output) maka hasil konversinya disebut dengan Intellectual Property atau dikenal dengan hak paten atau brand image perusahaan atau organisasi (Harrison \& Sullivan, 2000).

Pengembangan SC sebagai komponen kedua dalam ICM bertujuan mengkonversi $\mathrm{HC}$ dalam meningkatkan (upgrade) nilai hingga menciptakan kekayaan lembaga. Peran ini menegaskan bahwa SCM berkedudukan sebagai infrastruktur perwujudan (embodiment), pemberdayaan (empowerment) dan pendukung (supportive) $\mathrm{HC}$ lembaga (Boisot, 2002). Membangun SC berkualitas, tidak terlepas dari mengelola tiga aspek penting berikut (Zyl, 2005): 1. Modal

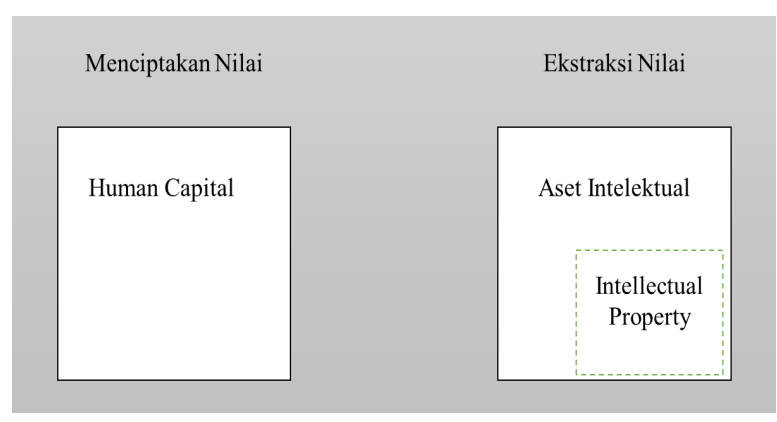

Gambar 4 Konversi Intellectual Asset menjadi Intellectual Property (Harrison \& Sullivan, 2000)

organisasi (mencakup semua sistem komputer yang ada, saluran distribusi dan pasokan, filosofi perusahaan, dan budaya organisasi); 2. Modal inovasi (kemampuan organisasi untuk menciptakan produk dan jasa yang merepresentasikan nilai tambah baru bagi pelanggan dan -terutamameliputi paten dan merek); dan 3. Modal proses (pengembangan, pemeliharaan dan pengelolaan yang efisien terhadap proses dan metodologi bisnis organisasi yang unik dan sulit untuk ditiru oleh para kompetitor menghasilkan sebagai pioneer dalam keuntungan berkepanjangan dan berdaya saing. 
Pengembangan RC sebagai komponen ketiga dalam ICM, dikenal juga dengan istilah external capital (modal eksternal) dan customer capital (modal pelanggan). RC ini sebagaimana didefinisikan sebelumnya yakni sebagai nilai yang diciptakan organisasi melalui hubungan dengan lingkungan eksternal seperti penyelenggara, pelanggan, pelanggan potensial, pengguna, penjual dan organisasi lain.

Istilah customer capital sendiri bermakna bahwa inovasi dan nilai dari organisasi dirasakan oleh customer. RC merupakan bagian yang penting dalam proses evaluasi nilai/produk organisasi, sebagai tolak ukur keberhasilan apakah produk atau nilai yang dihasilkan lembaga sesuai dengan pasar atau konsumen atau sebaliknya. Inti dari RC ini adalah pengetahuan yang tertanam dalam hubungan kolaboratif di luar organisasi

Berdasarkan uraian di atas, secara sistematis dapat dideskripsikan bahwa human capital merupakan sumber daya yang membangun blok untuk mengkonstruksi structural capital lembaga dan modal keduanya berinterkasi menciptakan relational capital untuk menciptakan nilai (value). Nilai bisa berbentuk kualitas dan kuantitas, bentuk produk atau pun servis atau jasa. Semakin sering ketiga sumber daya berinteraksi melalui pengetahuan, maka semakin besar pula nilai yang akan didapatkan organisasi.

\section{Intellectual Capital Report}

Penyempurnaan konsep ICM terletak pada pengukuran (measurement), karena pengujian suatu teori ilmu membutuhkan pengukuran (Ross $\&$ et al., 2001). Sebagai tahapan akhir dalam sebuah proses manajemen, laporan (report) berbentuk perhitungan/pengukuran dan pelaporan digunakan untuk evaluasi internal dan sebagai komunikasi memperbaiki kinerja eksernal, bertujuan untuk mengetahui seberapa efektif dan efisien semua komponen IC lembaga pemerintah dalam mengembangkan dirinya melalui aktualisasi konversi kompetensi ke dalam nilai. Laporan ICM yang dipublikasikan sangat penting baik bagi kalangan internal maupun eksternal untuk mengimprovisasi dan memahami perkembangan kompetensi organisasi.

Pada dasarnya ICM report ini digunakan untuk evaluasi internal dan sebagai komunikasi memperbaiki kinerja intenal (Marr \& Gray, 2006) namun laporan ICM juga signifikan untuk dipublikasikan kepada kalangan eksternal yaitu stakeholder yang menjadi mitra perusahaan atau organisasi agar mereka dapat menilai perkembangan kemitraan mereka selama berlangsungnya kerjasama.

Perhitungan dan laporan ICM mempunyai metode pengukuran dan pelaporan yang berbedabeda. Hal tesebut dikarenakan masing-masing pengukuran dan perhitungan mempunyai tujuan dan obyek fokus spesifik perhitungannya tersendiri. Adapun model pengukuran IC yang digunakan dalam penelitian ini menggunakan metode laporan perspektif Eropa the Danish Guidelines yang telah diuji lebih dari 100 perusahaan pada saat awal kemunculannya pada tahun 2000 (Mouritsen \& et al., 2003).

Metode Danish Guidelines secara operasional disebut sebagai metode laporan Intellectual Capital Statement (ICS). Statement (pernyataan) narasi sering menjadi penjelas dalam laporan untuk menunjukkan keberadaan perkembangan perusahaan atau lembaga, hal inilah menjadi sisi pentingnya pernyataan dalam bentuk kalimat narasi yaitu untuk menjelaskan hubungan dan strategi lembaga dalam mengembangkan IC dan mencapai sasaran visi dan misi lembaga yang dihubungkan dengan pengetahuan. Dalam hal ini, pengetahuan dapat berupa informasi, wawasan, pemikiran, dan sebagainya. Pengetahuan ini nantinya yang akan mengembangkan lembaga melalui inovasi, pelayanan, sosialisasi, dan sebagainya. Melalui ICS akan ditranslasikan peran pengetahuan pada lembaga.

Secara internal, Intellectual Capital Statement bertujuan untuk:

a. Mengelola dan mengembangkan sumber daya pengetahuan dalam perusahaan atau organisasi.

b. Membantu manajemen pengetahuan dengan sistematik, menambah inisiatif lain yang relevan serta mengembangkan strategi yang tepat untuk manajemen pengetahuan.

c. Mengendalikan strategi perusahaan terhadap manajemen pengetahuan dengan pemutakhiran pengetahuan yang logis dan konsisten dan pendekatan sistematis untuk mengelola dan berbagi pengetahuan, yang mendukung strategi umum perusahaan.

ICS menggunakan empat klasifikasi atau jenis sumber daya pengetahuan (knowledge resources) yaitu karyawan, pelanggan, proses dan teknologi. Dalam sebuah lembaga, manajemen pengetahuan (knowledge management) berkelindan dengan keempat jenis sumber pengetahuan tersebut dan interaksi diantaranya(Mouritsen \& et al., 2003).

Dalam pengimplementasiannya, Danish Guidelines fokus pada hubungan antara berbagai macam sumberdaya secara narasi yang terdiri dari empat komponen yaitu(Mouritsen \& et al., 2003) : a. Narasi pengetahuan. 
Narasi pengetahuan menggambarkan ambisi lembaga untuk meningkatkan nilai dari produk atau pelayanan lembaga terhadap pengguna. Ambisi ini disajikan dalam bentuk narasi karena menunjukkan pengetahuan pengguna dan lembaga. Narasi pengetahuan diidentifisikan dengan kata-kata "karena", "oleh sebab itu", dan "supaya".

b. Manajemen Tantangan

Manajemen tantangan meliputi deskripsi pengetahuan yang dimiliki dan pengetahuan yang dibutuhkan untuk memenuhi ambisi lembaga.
Tabel 2. Intellectual Capital Statement Model

(Mouritsen \& et al., 2003)

\begin{tabular}{|c|c|c|c|}
\hline Narasi Pengetahuan & $\begin{array}{c}\text { Manajemen } \\
\text { Tantangan }\end{array}$ & Inisiatif & Indikator \\
\hline $\begin{array}{l}\text { What product or } \\
\text { service does the } \\
\text { company provide? } \\
\text { - What makes a } \\
\text { difference for the } \\
\text { consumer? } \\
\text { - What knowledge } \\
\text { resources are } \\
\text { necessary to be } \\
\text { able to supply the } \\
\text { product or service? } \\
\text { What is the } \\
\text { relationship } \\
\text { between value and } \\
\text { - knowledge } \\
\text { resources? }\end{array}$ & $\begin{array}{l}\text { - Which existing } \\
\text { knowledge } \\
\text { resources should } \\
\text { be srengthened? } \\
\text { - What new } \\
\text { knowledge } \\
\text { resources are } \\
\text { needed? }\end{array}$ & $\begin{array}{l}\text { - What } \\
\text { initiatives can } \\
\text { be launched? } \\
\text { - What } \\
\text { initiatives } \\
\text { should be } \\
\text { prioritised? }\end{array}$ & $\begin{array}{l}\text { - Which } \\
\text { indicators can } \\
\text { each initiative } \\
\text { have? } \\
\text { Indicators can } \\
\text { measure: } \\
\text { 1. effect } \\
\text { 2. activities } \\
\text { 3. resource mix }\end{array}$ \\
\hline
\end{tabular}

c. Inisiatif

Inisiatif yaitu strategi untuk mengembangkan dan menciptakan inovasi atas tantangan lembaga yang dihadapi.

d. Indikator

Indikator yaitu komponen tolak ukur yang digunakan dalam inisiatif, yang dapat diukur dengan melihat aspek efektif dan efisiensinya.

\section{METODE PENELITIAN}

Penelitian ini menggunakan pendekatan kualitatif deskriptif. Metode pengumpulan data dilakukan melalui metode studi literatur dengan cara menelaah, menggali, serta mengkaji teoriteori yang relevan dengan permasalahan yang diteliti dari buku-buku referensi yang relevan, jurnal ilmiah, hasil penelitian sebelumnya, maupun artikel-artikel ilmiah, dan internet yang relevan dengan penerapan intellectual capital management guna menghasilkan informasi yang mendalam dan komprehensif mengenai permasalahan terkait. Dari analisis kualitatif, diharapkan akan diperoleh kajian ilmiah tentang operasionalisasi ICM secara holistik sebagai model manajemen untuk revitalisasi penyelenggaraan $e$ government di Indonesia.

\section{PEMBAHASAN}

Penelitian ini dilakukan untuk mengembangkan konsep baru dalam implementasi $e$ government secara sistematis dan praktis. Keberhasilan implementasi program e-government dapat dilakukan dengan memanfaatkan intangible assets yang dimiliki LPPEG. Aset nonmeneter lembaga yang seringkali terabaikan dari perhitungan yang memberikan keuntungan/nilai bagi lembaga ini, merupakan katalisator bagi pengimplementasian e-government di Indonesia. Melalui
ICM, intangible assets LPPEG dikelola secara sistematis dan praktis untuk menghasilkan nilai lembaga di hadapan pemangku kepentingan.

Formulasi ICM e-government diperoleh dengan cara mengkonstruksikan definisi ICM. Dengan memasukkan unsur-unsur kebutuhan pokok revitalisasi e-government, diperoleh kriteria yang membatasi dan mengindentifikasi ciri khusus ICM e-government. Intellectual Capital Management e-government untuk revitalisasi implementasi e-government adalah sebagai berikut:

\section{Pertama, Mengidentifikasi pemangku kepentingan utama e-government.}

Proses ini memungkinkan LPPEG untuk fokus pada pemangku kepentingan yang tepat dan signifikan bagi domain implementasi $e$ government. Stakeholder berperan penting dalam implementasi ICM di LPPEG, karena hasil dari proses ICM sendiri ditujukan untuk menciptakan nilai produk LPPEG di hadapan guna memenuhi kepuasan stakeholder. Posisi tingkat ketergantungan stakeholder e-government berdasarkan empat sifat stakeholder yang dikemukakan Frooman (1999), tingkat ketergantungan antara stakeholder dengan LPPEG termasuk tipologi saling bergantung (high interpendence).

Adapun yang menjadi stakeholder primer di lingkungan LPPEG terdiri dari: 1. Pegawai LPPEG (komponen e-government); 2. Masyarakat; 3. Pelaku Bisnis 4. Lembaga Pemerintah lainnya 5. Pemasok keperluan lembaga dan sebagainya. Sedangkan, stakeholders sekunder adalah media dan LSM dengan kapasitasnya memobilisasi opini publik dalam kebaikan, atau menjadi oposisi bagi kinerja lembaga. 
Kedua, Mengidentifikasi dan mengimplementasikan tiga komponen intangible assets.

Dalam penelitian ini, ICM $e$ government didefinisikan sebagai sistem yang mengorganisir komponen IC yakni human capital, structural capital dan relational capital LPPEG yang berintegrasi mentransfer dan mentransformasi pengetahuan ke dalam nilai yang lebih baik bagi pengembangan $e$ government.

\section{Human Capital Management e-government}

$\mathrm{HC}$ yang terdapat di lingkungan LPPEG adalah SDM lembaga dan berkontribusi aktif bagi kesuksesan lembaga dalam berinovasi dan menghasilkan keuntungan yang sustainable (berkelanjutan). Dengan demikian, SDM yang berpotensi menjadi HC di LPPEG adalah pemimpin dan pegawai LPPEG.

Peran strategis SDM LPPEG tersebut -sebagai sumber daya lembaga-menjadi penentu keberhasilan pencapaian kinerja terbaik lembaga. Hanya SDM yang dapat menciptakan pengetahuan dan sekaligus memiliki pengetahuan yang bisa menjadi HC lembaga. Hal ini menegaskan bahwa HC merupakan komponen penting untuk suksesnya LPPEG.

Pemimpin dan pegawai yang berada di lingkungan LPPEG menjadi sumber daya bagi LPPEG melalui kompetensi (competence), sikap (attitude), dan kecerdasan intelektual (intellectual agility)

Regulasi pemerintah yang berlaku menun-
Kompetensi ASN adalah deskripsi pengetahuan, keterampilan dan perilaku yang diperlukan seorang Aparatur Sipil Negara dalam melaksanakan tugas jabatan (Pasal 1 ayat 1). Kompetensi Teknis adalah pengetahuan, keterampilan, dan sikap/perilaku yang dapat diamati, diukur dan dikembangkan yang spesifik berkaitan dengan bidang teknis jabatan (Pasal 1 ayat 7). Kompetensi Manajerial adalah pengetahuan, keterampilan, dan sikap/perilaku yang dapat diamati, diukur, dikembangkan untuk memimpin dan/atau mengelola unit organisasi (Pasal 1 ayat 8). Kompetensi Sosial Kultural adalah pengetahuan, keterampilan, dan sikap/perilaku yang dapat diamati, diukur, dan dikembangkan terkait dengan pengalaman berinteraksi dengan masyarakat majemuk dalam hal agama, suku dan budaya, perilaku, wawasan kebangsaan, etika, nilai-nilai, moral, emosi dan prinsip, yang harus dipenuhi oleh setiap pemegang Jabatan untuk memperoleh hasil kerja sesuai dengan peran, fungsi dan Jabatan (Pasal 1 ayat 9).

jukkan bahwa dimensidimensi tersebut termaktub dengan jelas dalam Permenpan-RB No. 38 Tahun 2017 tentang Standar Kompetensi Jabatan Aparatur Sipil Pasal 4 ayat $2 \mathrm{~b}$ a h w a s t a n d a r kompetensi jabatan yang wajib dimiliki oleh pegawai ASN, yakni kompetensi teknis, kompetensi manajerial, dan kompetensi sosial kultural. Standar Kompetensi Jabatan Aparatur Sipil Negara yang selanjutnya disebut Standar

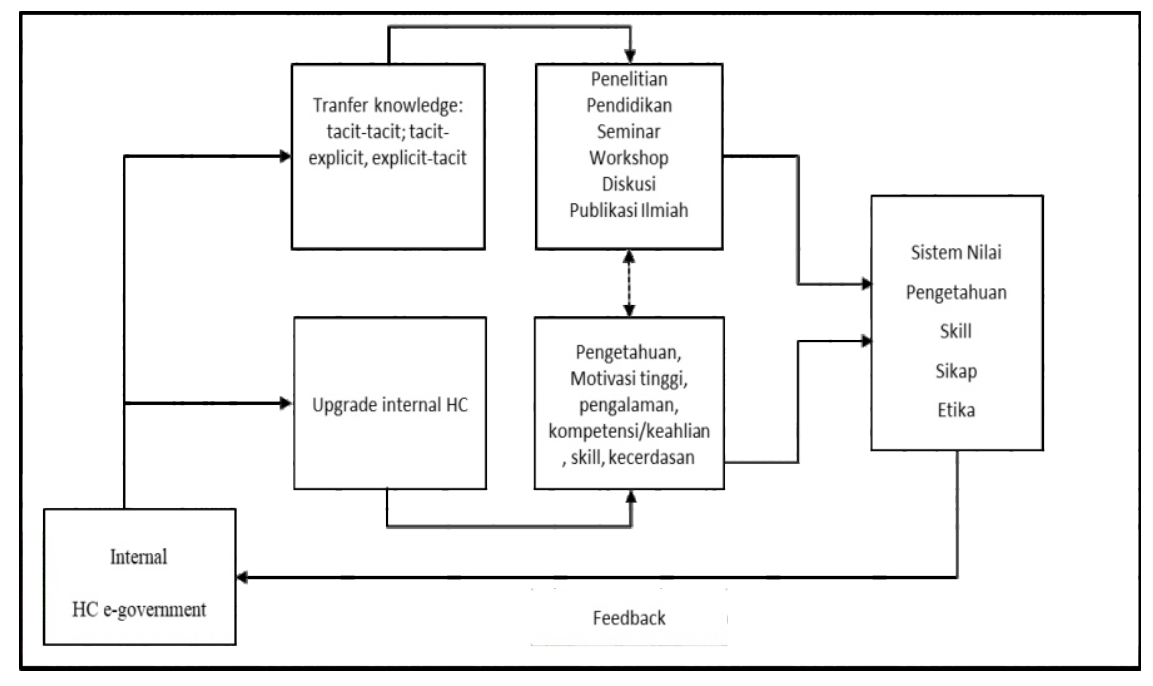

Gambar 4. Human Capital e-government (Peneliti) 
Sumber daya sebagaimana yang diatur dalam peraturan menteri tersebut merupakan prasyarat dalam memampukan kinerja SDM LPPEG yang terdiri dari perpaduan antara kompetensi (competence), sikap (attitude), dan kelincahan intelektual (intellectual agility), yang dalam istilah ICM pemimpin maupun pegawai menghasilkan sumber daya bagi LPPEG melalui ketiga kompetensi tersebut sehingga menjadi sumber daya bagi HC lembaga. Kompetensi secara umum berkelindan dengan level pendidikan formal SDM (Kelly, 2004). Sumber daya kompetensi, menghasilkan nilai bagi LPPEG melalui know how yang dihasilkan secara individu dan kolektif. Seperti kemampuan menyelesaikan masalah yang muncul dalam pekerjaan, pengetahuan teknik $e$ government, keterampilan manajerial terhadap aktivitas rutin mengelola kelompok-kelompok pekerjaan yang bevariasi, dan keterampilan hubungan masyarakat, yakni kemampuan dasar untuk membangun hubungan positif (etika) dengan kolega, keterampilan memotivasi, memahami dan mempengaruhi kolega dan orang luar yang dipandang enggan untuk bertindak untuk kepentingan lembaga daripada diri mereka sendiri.

Korelasi antara pengetahuan dan keterampilan diibaratkan dengan pengetahuan adalah pertimbangan teoretis, maka mitra praktisnya adalah keterampilan. Rasionalisasinya, SDM LPPEG yang tidak memiliki keterampilan mengimplementasikan pengetahuan yang dimilikinya, maka pengetahuan tersebut tidak bermanfaat bagi lembaga. Demikian halnya dengan modal sikap (attitude). Modal ini merupakan mitra pengimbang bagi kedua modal lainnya (pengetahuan dan keterampilan) (Kelly, 2004) membantu HC LPPEG membangun lingkungan kerja yang positif, pribadi dan etos kerja yang positif, hubungan interpersonal positif, dan mendukung daya inovasi dan kreativitas. Di lingkungan LPPEG, setiap pegawai harus mampu meningkatkan kualitas dirinya dan berpegang teguh untuk melakukan pengembangan keterampilan dan pengetahuan. Hal ini bertujuan agar pegawai akan memiliki kemampuan yang bagus untuk terkait pekerjaannya.

Aspek sikap (attitude), LPPEG tidak dapat mengelola aspek ini karena sepenuhnya bergantung pada individu SDM. Attitude adalah sikap dan perilaku keseharian pegawai, seperti cara berbicara, bertindak, termasuk cara memperlakukan orang lain. Attitude sangat berkaitan dengan periaku kerja dan etos kerja(Kelly, 2004).

Pada aspek kelincahan intelektual (intellectual agility), dalam pengelolaan LPPEG diperlukan tidak sekedar intellectual agility melainkan dua aspek agility lainnya yang masuk dalam dimensi personal agility yaitu emotional agility dan physical agility. Hal ini dilatarbelakangi oleh dunia e-government yang dinamis menuntut diperlukannya individu dengan sumber daya personal agility.

Personal agility (Clark, 2008) adalah kualitas personal, terdiri dari tiga dimensi :

1. Intellectual agility, yang memiliki ciri-ciri sebagai berikut: luas dan dalamnya pengetahuan yang relevan, keterampilan berpikir kritis dan analitis, kreativitas, keterampilan berinovasi, keingintahuan, sumber daya dan fleksibilitas kognitif, Pembelajaran berkelanjutan, penguasaan perilaku dan keterampilan baru, keberanian intelektual untuk menghadapi kenyataan dan menghindari penolakan;

2. Emotional agility, terdiri dari: berenergi, kuat dan berdaya saing, kemampuan mengendalikan emosi dalam menghadapi ketegangan, adaptabilitas, fleksibilitas, optimisme, keyakinan diri, self esteem, toleransi dalam menghadapi ketidakpastian, keraguan dan keterkejuta, komitment dan kegigihan meski menghadapi kesulitan dan penentangan, disiplin dan kemampuan menunda kenikmatan; motivasi menghadapi tantangan, kemauan bekerja tanpa mengharapkan pengakuan.

3. Physical agility, terdiri dari: kapasitas fisik untuk mencapai maksimal; kapasitas fisik untuk bekerja diluar jadwal, daya tahan dan stamina kemampuan berkonsentrasi, toleransi terhadap kegiatan yang membosankan dan halhal yang terlalu biasa.

Merujuk pada pendekatan pengembangan ilmu pengetahuan (knowledge improvement approach) ICM, secara kelembagaan, diperlukan upaya pembinaan terhadap kompetensi SDM LPPEG yang berkedudukan sebagai unsur aparatur negara dengan tugas utama memberikan pelayanan kepada masyarakat. Pembinaan tersebut akan meningkatkan kinerja mereka dalam pelaksanaan tugas pokok, fungsi kewenangan dan tanggungjawab yang diamanatkan kepadanya selama bekerja di LPPEG. Upaya yang dapat dilakukan untuk membangun kompetensi individu tersebut untuk menjadi HC lembaga, diantaranya melalui penelitian, pendidikan (memberikan kesempatan untuk melanjutkan pendidikan ke tingkat yang lebih tinggi, menyekolahkan kembali ke luar negeri), workshop, seminar, publikasi ilmiah.

Intellectual capital e-government, seperti halnya IC dalam dunia bisnis, bertumpu pada 
kualitas SDM. Kompetensi SDM tersebut menjadi faktor berpengaruh yang signifikan menumbuhkan keunggulan kompetitif lembaga melalui kemampuannya untuk berinovasi dan berpikir 'outside the box' terkait pekerjaannya dan menghasilkan solusi baru untuk menyelesaikan berbagai permasalahan pekerjaan yang dihadapi (Kelly, 2004).

Melalui ICM, SDM akan lebih memahami dimana letak pengetahuannya (core knowledge) dalam lembaga tersebut. Fakta meunjukkan bahwa semakin esensial mereka, semakin besar kemungkinan mereka bergerak dalam banyak hal di internal lembaga. Melalui penciptaan pengetahuan, SDM berprestasi dapat menjadi sumber daya pengetahuan LPPEG. Eksistensi SDM dalam lembaga e-government berbanding lurus dengan kualitas lembaga. Sebagaimana karakter organisasi pembelajar, bahwa semakin berkualitas SDM sebuah lembaga, maka akan semakin berkualitas lembaga tersebut.

\section{Structural Capital Management E-government}

Aset tidak berwujud (intangible assets) kedua yang harus diperhatikan dan dikelola untuk revitalisasi impelmentasi e-government adalah sumber daya struktural (structural capital). SC mencakup keseluruhan aset tidak berwujud (intangible) yang dimiliki LPPEG yang memberi nilai tambah bagi keseluruhan proses, rutinitas, dan infrastruktur lembaga, sehingga aset ini akan tetap ada sekalipun pemimpin dan para staff/ pegawai meninggalkan lembaga. Hal ini menegaskan bahwa SC dimaksud bukan berbicara tentang fisik lingkungan lembaga melainkan kemampuan lembaga secara struktural dalam memfasilitasi hubungan antar individu lembaga (connecting people) dan mendukung terhadap penciptaan pengetahuan (capture of knowledge) untuk menghasilkan kinerja intelektual yang optimal dan kinerja bisnis secara keseluruhan.

Pengelolaan SC LPPEG, merupakan faktor penting dalam pengimplementasian e-government berkualitas. Sebagaimana hasil penelitian Fukuyama dalam Harimurti(2010) bahwa kemampuan kelembagaan berpengaruh pada pengembangan e-government berkualitas. Optimalisasi peran SC membantu lembaga menciptakan nilai yang lebih baik lagi bagi lembaga dengan berbasis pengetahuan, sesuai dengan fungsinya sebagai infrastruktur perwujudan (embodiment), pemberdayaan (empowerment) dan pendukung (supportive) HC lembaga.

Peran ini diimplementasikan dalam bentuk mengonversi $\mathrm{HC}$, dimana kompetensi $\mathrm{HC}$ yang telah mempunyai pengetahuan dan keterampilan yang optimal, diejawantahkan secara terstruktur guna menghasilkan dan meningkatkan nilai serta menciptakan kekayaan LPPEG (menghasilkan IC berkualitas bagi lembaga). Meskipun sumber daya manusia lembaga memiliki pengetahuan yang tinggi jika tidak didukung oleh struktur lembaga yang memadai, maka kemampuan SDM tersebut tidak akan menghasilkan IC lembaga. Sehingga, memfasilitasi SDM lembaga untuk mengungkit (leverage) pengetahuan yang dimilikinya, menjadi keharusan bagi LPPEG guna meningkatkan kualitas kinerja yang diharapkan. Di sisi lain, untuk menciptakan keunggulan kompetitif yang berkelanjutan bagi lembaga, memenuhi kebutuhan publik dengan menunjukkannya dihadapan stakeholder berbagai keunggulan kompetitif berkelanjutan lembaga dan pioneer untuk keuntungan jangka panjang.

Dengan menyesuaikan pada konteks LPPEG sebagai pelayanan publik, dimensi SC yang harus dimiliki LPPEG agar menjadi IC lembaga merujuk pada teori yang dikemukakan Zyl (2005) terdiri dari: 1. Modal organisasi; 2. Modal inovasi; dan 3. Modal proses.

\section{Modal organisasi}

SC organisasi yang menjadi sumber daya LPPEG berkualitas sehingga menghasilkan IC lembaga terdiri dari:

a. Database (basis data) lembaga. Intangible asset lembaga ini terdiri dari kumpulan berbagai data dan informasi yang terintegrasi secara sistematis. Penggunaan sistem database dalam pengelolaan data LPPEG merupakan prasyarat untuk mendukung kegiatan-kegiatan yang ada di dalam lembaga, meliputi database pegawai, pengguna layanan, dan pelanggan. Dalam perspektif ICM, LPPEG harus memiliki database ini dikarenakan beberapa manfaat seperti, membantu mengembangkan proses perencanaan lembaga secara lebih efektif, menjamin ketersediaan kualitas dan keahlian SDM, mewujudkan data kepegawaian secara lebih mutakhir dan terintegrasi dan dapat meningkatkan aksesibilitas data agar dapat ditampilkan secara akurat dan tepat waktu. Hal ini diperlukan mengingat, masih banyak LPPEG di beberapa wilayah di Indonesia yang masih belum mengoptimalkan penggunaan database sebagai modal dalam mengimplementasikan e-government.

b. Teknologi Informasi dan Komunikasi (TIK). Penerapan TIK sangat diperlukan LPPEG yakni sebagai alat bantu agar lembaga dapat lebih maju dan berkembang, seperti database, 
network management, sistem operasi lembaga dan lain sebagainya. TIK membantu lembaga pemerintah untuk menunjang kinerja pemerintahan melalui program e-government (Utomo, 2016). Penggunaan TIK sebagai bagian dari operasional aktivitas di lingkungan lembaga pemerintahan termasuk LPPEG sudah dimulai sejak dikeluarkannya regulasi UU No. 30/2014 tentang Administrasi Pemerintahan Pasal 38 ayat 1-4. Undang-Undang ini menegaskan adanya transformasi dari birokrasi manual menjadi birokrasi digital di lingkungan lembaga pemerintahan, sehingga TIK menjadi bagian yang krusial dalam penyelenggaraan aktivitas pemerintahan. TIK LPPEG harus dapat memfasilitasi SDM bekerja dengan informasi dan melakukan tugas yang berhubungan dengan pemrosesan informasi (Kadir \& Triwahyuni, 2003). Dalam perspektif ICM, TIK mengubah SDM lembaga menjadi pengetahuan eksplisit termasuk diseminasi pengetahuan tersebut diantara pegawai dan stakeholder e-government. Hal ini akan membawa lembaga memiliki ingatan ekspilisit tentang prosedur kelembagaan. Kemampuan SDM LPPEG menguasai dan memanfaatkan TIK sebagai modal IC, menjadi tolak ukur keberhasilan lembaga dalam membangun ekosistem digital pengetahuan LPPEG di Indonesia.

c. Filosofi lembaga. Filosofi sebuah lembaga dibangun di atas keyakinan, nilai, aspirasi dan prioritas yang menjadi komitmen para pengambil keputusan serta tindakan strategis lembaga untuk dapat bertumbuh sesuai tujuan lembaga (Pearce \& Robinson, 2000). Filosofi lembaga sebagai software operasional yang membuat hidup LPPEG, harus dibangun diatas keyakinan, nilai, aspirasi, dan prioritas lembaga yang dapat mengantarkan HC LPPEG menjadi sumber pengetahuan eksplisit lembaga dan menyebarkan pengetahuan tersebut menjadi pengetahuan tacit diantara pegawai, stakeholder, dan masyarakat.

d. Budaya lembaga. Dalam perspektif ICM, LPPEG harus memiliki budaya pembelajaran, yakni budaya lembaga yang dibangun di atas sistem yang mengaplikasikan nilai-nilai dominan lembaga yang inovatif dan berorientasi pada dua aspek yakni berorientasi pada pelanggan dan berorientasi pada pengelolaan pengetahuan (Budihardjo, 2017). Melalui budaya pembelajaran, LPPEG akan mampu bersaing melalui inovasi dan pemenuhan kebutuhan stakeholder/masyarakat baik produk atau jasa.
Aspek yang ditekankan dari budaya pembelajaran adalah internalisasi pengetahuan explicit value lembaga (nilai-nilai lembaga) menjadi tacit value yang secara otomatis membentuk perilaku SDM lembaga. Penanaman budaya pembelajaran dapat dilakukan melalui proses sosialisasi, internalisasi, desiminasi baik berbentuk pembiasaan, pelatihan, rutinitas, keteladanan top management, dan kegiatankegiatan lainnya yang mendukung.

\section{Modal inovasi.}

Inovasi tidak dapat lepas dari kiprah LPPEG sebagai penyedia layanan publik berbasis teknologi informasi. Inovasi adalah refleksi kekuatan profesionalitas lembaga, yang belum dapat dirasakan dampaknya namun berpotensi menghasilkan nilai di masa depan.

Membangun LPPEG yang mendukung terhadap perolehan nilai-nilai inovatif dimanifestasikan dalam bentuk transformasi struktural yaitu pemberdayaan (empowerment) pengabdian dan pelayanan, pelayanan unggul (excellent service) dan organisasi pembelajar (learning organization). Transformasi ini mengedepankan terbentuknya empat kondisi yang memungkinkan dan mendukung terhadap kreativitas HC dalam menghasilkan inovasi lembaga, yaitu: 1 . Membuka peluang seluas-luasnya bagi SDM untuk ekspresi kreatif seperti investasi berbentuk pelatihan bagi SDM; 2. Mengatasi konflik lembaga. Berkumpulnya beberapa orang dalam satu visi seringkali memunculkan konflik. Diperlukan upaya mengatasi konflik dalam organisasi agar tetap berada dalam satu visi; 3 . Lembaga menyediakan sumber daya dan dukungan yang memadai untuk mengembangkan gagasan atau ide-ide pegawai yang menambah nilai inovasi lembaga; dan 4. Memberikan reward bagi pegawai berkualitas yang menguatkan dan meningkatkan motivasi intrinsik SDM untuk mendedikasikan dirinya bagi lembaga.

Adapun situasional yang harus dibentuk yang mendukung terhadap inovasi lembaga: 1 . Membangun lembaga dengan orientasi organisasional yang tinggi terhadap inovasi; dan 2. Menciptakan situasional yang mendukung ekspresi SDM dalam berinovasi, yakni lembaga menciptakan produk dan jasa yang merepresentasikan nilai tambah baru bagi publik sebagai pengguna produk/jasa LPPEG.

\section{Modal proses}

Pengembangan e-government bukanlah dalam bentuk produk atau cetak biru, melainkan 
merupakan sebuah proses yang harus sinkron merespon perkembangan yang dinamis dengan mengembangkan strategi mendukung tujuan nasional dan menciptakan reformasi birokrasi (Harimurti, 2010).

Peran lembaga signifikan menentukan implementasi strategi program e-government. Mengeksplorasi manajemen modal proses, dengan fokus utama pada manajemen proses dan metodologi layanan publik. Hal ini bertujuan bagaimana pengembangan, pemeliharaan dan pengelolaan yang efisien terhadap proses dan metodologi layanan publik $e$ government yang unik dan sulit untuk ditiru oleh para kompetitor sehingga menghasilkan posisi pioneer dalam keuntungan berkepanjangan dan berdaya saing.

Dalam aktivitas ICM, eksistensi LPPEG akan teruji rivalitas dan kompetensinya melalui nilai/ produk/layanan yang dihasilkannya. SC memainkan peran paling penting dalam implementasi $e$ government. Peran ini lebih mudah diimplementasikan untuk para pemangku kepentingan daripada dari jenis modal lainnya. Banyak kegiatan modal struktural dapat memberikan hasil yang jelas bagi masyarakat. Kegiatan ini didukung oleh pemerintah daerah yang memiliki semua sumber daya (pemerintah daerah memiliki tingkat partisipasi tertinggi untuk domain budaya masyarakat).

\section{Relational Capital Management E-government}

$\mathrm{RC}$ yang diimplementasikan dalam ICM $e$ government ini merupakan aktivitas lembaga yang berkaitan dengan upaya mengembangkan dan mempertahankan stakeholder dalam upaya untuk mengembangkan hubungan jangka panjang yang saling menguntungkan.

RC di LPPEG terdiri dari dua macam relasi, yaitu relasi sebagai penerima dan pengguna inovasi layanan e-government dari LPPEG yaitu masyarakat/warga negara, dan relasi sebagai pengguna dan pemeran yang membantu proses penyebarluasan inovasi e-government (mitra kerja), seperti para pelaku bisnis/pengusaha/media masa. Secara implisit, RC adalah kombinasi dari proses bisnis internal seperti penjualan, pemasaran, dan dukungan pelanggan dengan teknologi dan cara memperoleh data(Zyl, 2005).

Membangun interaksi relasi positif antara mitra internal dan mitra eksternal menjadi tema besar RCM LPPEG. Interaksi mitra internal RC engetahuan

dividu $\mathrm{HC}$
Intellectual Property

Lembaga Penyelenggara egovernment

Nilai/produk/layanan
Konversi

Gambar 5. Structural Capital e-government (Peneliti) menunjukkan tema hubungan SDM dengan sesama rekan kerja dengan prinsip saling percaya, rasa hormat dan persahabatan yang timbul dari interaksi yang erat. Adapun aspek eksternal RC menunjukkan tema hubungan LPPEG dengan HC lembaga yang berinteraksi dengan pelanggan/ stakeholder dan mitra kerja.

Membangun interaksi relasi di lingkungan LPPEG harus berorientasi pada diperolehnya peningkatan pengetahuan antar SDM, stakeholder, shareholder, dan masyarakat. ICM bekerja dengan memposisikan $\mathrm{RC}$ tidak hanya sebagai pihak konsumtif, namun juga bersifat korektif dan evaluatif terhadap produk/jasa/nilai yang diciptakan lembaga (LPPEG). RC memberikan impresi terhadap terbangunnya inovasi di lingkungan LPPEG melalui kecerdasan dalam membangun hubungan kolaboratif dengan stakeholder dan mitra kerja (hal ini sangat penting bagi organisasi manapun yang ingin menangkap dan menciptakan IC).

Inovasi dan nilai yang diberikan oleh $\mathrm{RC}$ dalam bentuk feedback, akan menjadi bahan evaluasi bagi lembaga untuk melakukan perbaikan dan pengembangan pengetahuan dalam menciptakan nilai lembaga yang lebih baik lagi. Oleh sebab itu, diperlukan upaya LPPEG (SC) untuk mempunyai dan membangun jaringan (networking) yang baik sebagai sarana pemasaran dan publikasi e-government kepada publik dan proses itu juga dapat menjadi bagian eksistensi lembaga dan keberlanjutannya. Adapun aspek yang harus diperhatikan untuk membangun hubungan tersebut mencakup kerjasama, kepercayaan, komitmen dan berbagi informasi, serta integrasi yang berhubungan dengan stakeholder dan mitra kerja. (Zyl, 2005). 
Rasionalisasinya di lapangan bahwa stakeholder dan mitra kerja memiliki peluang memberi masukan progresif kepada LPPEG terkait produk/jasa e-government. Untuk itu diperlukan menyediakan ruang publik untuk menampung masukan-masukan dari eksternal lembaga dan bersifat transparan.

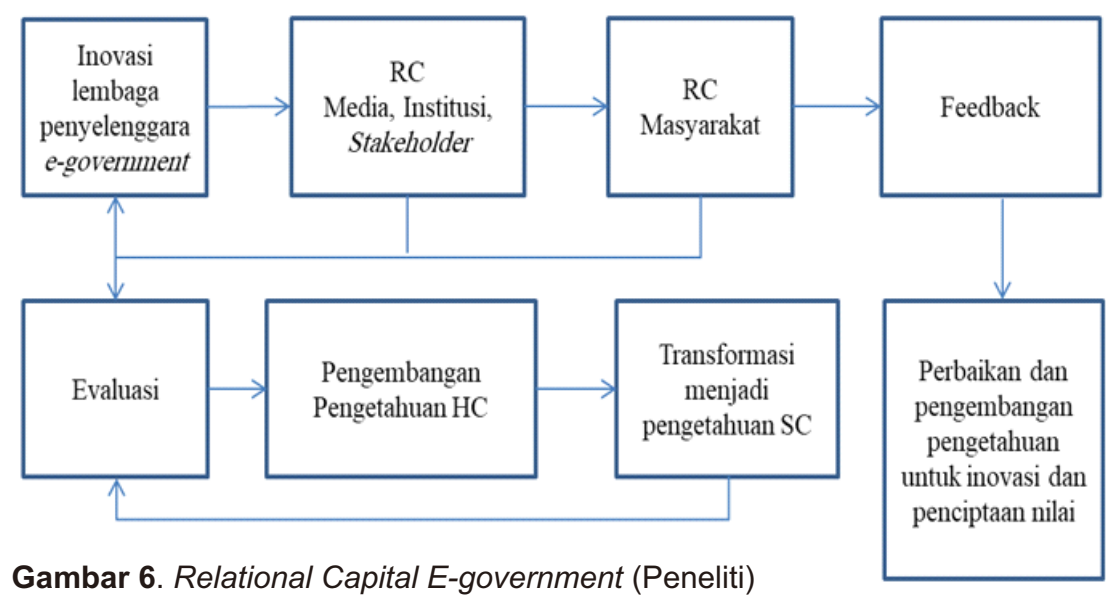

\section{Ketiga, Kodifikasi pengetahuan (transfer dan penciptaan pengetahuan).}

Proses ICM di lingkungan LPPEG bergantung pada kemampuan dalam mengelola pengetahuan di lembaga, sehingga tidak dapat dilepaskan dari proses transfer dan penciptaan pengetahuan lembaga yakni melalui interaksi antara pengetahuan tacit dan explicit. Interaksi keduanya mengarah pada penciptaan pengetahuan baru. Membangun LPPEG berkualitas melalui pengoptimalan pengetahuan perspektif ICM dapat dilakukan dengan dua pendekatan yaitu,

1. Pendekatan pengembangan ilmu pengetahuan (knowledge improvement approach). Pada pendekatan ini, LPPEG melakukan internalisasi pengetahuan ke dalam individu/staf internal lembaga. Pengetahuan yang dimiliki individu, dikembangkan dan didiseminasikan melalui proses transfer pengetahuan baik antar individu, individu-kelompok, maupun berbentuk kodifikasi (individu kepada lembaga)

2. Pendekatan efektifitas pengetahuan (knowledge effectiveness approach). LPPEG melakukan dua kegiatan utama yaitu pertama, pendekatan evaluasi yang terdiri dari pengukuran dan perhitungan; dan Kedua, report (laporan) yakni memberikan pelaporan kepada stakeholder dan shareholder e-government.

Rasionalisasinya di LPPEG ini bahwa saat proses transfer pengetahuan dari satu kategori ke kategori lainnya, akan menghasilkan pengetahuan sebagai berikut:
1. Tacit-tacit. SDM LPPEG baik secara individu maupun kolektif, berbagi pengalaman (pengetahuan tacit) melalui komunikasi langsung (tatap muka). Pada tingkat individu, transfer pengetahuan model ini berbentuk pendidikan dan pelatihan, wawancara, sosialisasi, pengajaran, praktik. Demikian halnya dengan transfer pengetahuan lingkup stakeholder, berbagi pengalaman yang dibutuhkan dalam implementasi $e$ government dapat dilakukan dalam bentuk kerjasama, kemitraan, merger, dan akuisisi antar lembaga baik nasional maupun internasional, seperti pertukaran pegawai, workshop internasional, mengundang instruktur (para ahli) dari luar departemen baik nasional maupun inter$\mathrm{n}$ a s i o n a 1 . M e 1 a $1 \mathrm{u}$ i pembelajaran dari pengalaman dan berbagi pendapat antara satu dengan yang lain lebih memudahkan untuk memahami pengetahuan.

2. Tacit-explicit. Berlanjut dari transformasi pengetahuan tacit-tacit berbentuk tukar pengalaman, akan diidentifikasi kebutuhan dan harapan yang berhubungan dengan pengimplementasian e-government. Kombinasi dari pengetahuan tacit dan explicit menjadi pengetahuan yang tertanam di LPPEG. Seperti, pendokumentasian pengalaman individu dalam bentuk buku, artikel, jurnal atau dokumentasi lainnya. Membangun pengetahuan $e-$ government yang bersifat abstrak (tacit) menjadi konkret ini, membantu LPPEG melakukan penyimpanan pengetahuan individu SDM menjadi properti lembaga, seperti buku panduan cara mengoperasikan sistem aplikasi e-government, dokumentasi standar operasional prosedur (SOP) tata kelola e-government, dan sebagainya. Hal ini memudahkan stakeholder internal dan stakeholder eksternal yang ingin menggunakannya dapat lebih mudah memahami pengetahuan tersebut. Aspek yang harus diperhatikan dalam proses pengkodifikasian ini adalah kecermatan, keterbacaan, aksesibilitas, keterbaruan, serta kredibilitas (Dalkir dalam Budihardjo (2017).

3. Explicit-tacit. Personalisasi pengetahuan dan pengalaman, yang telah terkodifikasi, oleh individu dari dokumentasi. Individu lembaga belajar dan melakukan perubahan dari penga- 
laman orang lain yang telah dikodifikasikan. Pengetahuan explicit menjadi bagian dari basis pengetahuan individu. Misalnya, LPPEG menerima pengetahuan untuk mengelola pemangku kepentingan; stakeholder eksternal menerima pengetahuan untuk mengoperasikan program e-government, baik stakeholder internal maupun stakeholder eksternal belajar satu sama lain dan menemukan cara baru mengelola e-government secaraa bersama. Contohnya, menjalankan prosedur kerja pegawai e-government sesuai dengan dokumen SOP yang telah ditetapkan.

Transfer pengetahuan e-government sebagai bentuk feedback juga diperlukan dari relasi LPPEG, atas kinerja LPPEG selama ini dalam rangka diseminasi dan implementasi $e$ government.

Selain itu, kodifikasi pengetahuan yang memuat aturan dan prosedur operasional $e$ government (e-budgeting, e-procurement, e-audit, e-catalog, e-payment, e-controlling, e-health) akan memungkinkan masyarakat dalam memanfaatkan secara maksimal pelayanan publik dari pemerintah sehingga secara tidak langsung berperan aktif dalam mengontrol pekerjaan pemerintah, dan untuk membantu terwujudnya bangsa yang melek e-literacy. (teknologi informasi dan komunikasi)

Tabel 3. Contoh Intellectual Capital Statement Aspek HC (Peneliti)

\begin{tabular}{|c|c|c|c|}
\hline Narasi Pengetahuan & $\begin{array}{c}\text { Manajemen } \\
\text { Tantangan }\end{array}$ & Inisiatif & Indikator \\
\hline $\begin{array}{l}\text { Pemeringkatan } \\
\text { implementasi e- } \\
\text { government } \\
\text { Indonesia masih } \\
\text { berada di level } \\
\text { rendah karena } \\
\text { kompetensi SDM dan } \\
\text { tingkat melek e- } \\
\text { literacy masyarakat } \\
\text { masih rendah, oleh } \\
\text { sebab itu diperlukan } \\
\text { sistem manajemen } \\
\text { untuk mengungkit } \\
\text { pengetahuan dan } \\
\text { daya inovasi supaya } \\
\text { SDM lembaga } \\
\text { penyelenggara e- } \\
\text { government dan } \\
\text { masyarakat dapat } \\
\text { berkontrbusi dan } \\
\text { berpartisipasi aktif } \\
\text { dalam meningkatkan } \\
\text { kualitas layanan } \\
\text { publik e-government }\end{array}$ & $\begin{array}{l}\text { Saat ini pengelolaan } \\
\text { pengetahuan e- } \\
\text { government secara } \\
\text { sistematiksebagai } \\
\text { salah satu cara } \\
\text { memaksimalkan } \\
\text { implementasi e- } \\
\text { government belum } \\
\text { dikelola secara } \\
\text { khusus/professional. } \\
\text { Diperlukan upaya } \\
\text { pengelolaan } \\
\text { pengetahuan } \\
\text { melalui penguatan } \\
\text { pengetahuan SDM, } \\
\text { organisasi dan } \\
\text { kolaborasi dengan } \\
\text { relasi dalam upaya } \\
\text { revitalisasi e- } \\
\text { government. }\end{array}$ & $\begin{array}{l}\text { Sosialisasi } \\
\text { system } \\
\text { penciptaan } \\
\text { pengetahuan di } \\
\text { lembaga } \\
\text { penyelenggara e- } \\
\text { government. } \\
\text { Menciptakan } \\
\text { iklim lembaga } \\
\text { yang mendukung } \\
\text { terhadap } \\
\text { pengelolaan } \\
\text { pengetahuan. }\end{array}$ & $\begin{array}{l}\text { Menyelenggara } \\
\text { kan pelatihan } \\
\text { dan pendidikan } \\
\text { pengelolaan } \\
\text { pengetahuan } \\
\text { (tacit dan } \\
\text { explicit) secara } \\
\text { formal dan } \\
\text { sistematik yang } \\
\text { mendukung dan } \\
\text { mensupport } \\
\text { SDM untuk } \\
\text { terus } \\
\text { meningkatkan } \\
\text { pengetahuannya } \\
\text { mengadakan } \\
\text { pembinaan yang } \\
\text { meningkatkan } \\
\text { motivasi dan } \\
\text { mendorong } \\
\text { terciptanya etos } \\
\text { kerja, } \\
\text { komitmen, dan } \\
\text { kinerja optimal. }\end{array}$ \\
\hline
\end{tabular}

Keempat, Identifikasi masalah, melakukan evaluasi, dan membuat laporan secara berkala kepada stakeholder e-government tentang perkembangan implementasi ICM dan lembaga melalui Intellectual Capital Statement e-government

Elemen terakhir yang menjadi bagian dari ICM adalah pelaporan (report) Intellectual Capital Danish Guideline atau yang dikenal dengan Intellectual Capital Statement. Menggunakan format kerja pelaporan ICS ini akan diperoleh pengetahuan terkait informasi, wawasan, pelayanan, dan sosialisasi pengelolaan ICM $e$ government dalam bentuk narasi sehingga pelaporan yang dipublikasikan kepada kalangan eksternal lembaga lebih komprehensif.

Urgenitas pelaporan ini adalah sebagai acuan bahan pertimbangan bagi para stakeholder dan mitra kerja dalam bekerjasama dan memberikan suport terhadap inovasi produk dan pelayanan publik e-government dalam menguatkan sistem pelayanan publik terutama tata kelola transparansi sistem informasi publik di lembaga pemerintahan. Tabel 3 adalah contoh ICS yang diterapkan dalam aspek HC.

\section{PENUTUP}

Dalam perkembangannya, pemerintah selama ini telah berupaya untuk meningkatkan kualitas implementasi e-government. Melalui eksistensi lembaga pemerintahan penyelenggara $e$ government (LPPEG), berbagai upaya dilakukan pemerintah untuk dapat memfasilitasi masyarakat dengan layanan publik sesuai dengan kebutuhan pengguna.

Ketidakseimbangan mengelola aset LPPEG antara tangible assets dan intangible assets, menjadi pemicu rendahnya tingkat keberhasilan pengimplementasian e-government Indonesia di tingkat dunia selama ini. Upaya revitalisasi implementasi e-government di Indonesia aspek intangible assets dalam rangka mendongkrak kualitas implementasi e-government merupakan program kerja pemerintah yang bersifat mendesak untuk segera dilakukan dan menuntut keseriusan pemerintah dalam merealisasikannya secara 
berkesinambungan.

Proyeksi revitalisasi implementasi $e$ government melalui ICM dapat meningkatkan taraf melek e-literacy warga negara dan terciptanya good governance. Dengan mengorganisir tiga komponen IC (HC, SC, dan RC), ICM egovernment merupakan tools untuk aktivasi ketiga komponen tersebut dalam upaya revitalisasi $e$ government. Proses pelaporan perkembangan IC e-government kepada shareholder dan stakeholder (pendekatan efektifitas) melalui metode Intellectual Capital Statement Danish Guidline Report dengan menggunakan pelaporan berbentuk narasi, memudahkan shareholder dan stakeholder untuk memahami perkembangan implementasi $e$ government dan memudahkan proses pemecahan masalah secara mendalam.

Diharapkan inovasi layanan publik yang dihasilkan ICM dapat meningkatkan kualitas implementasi e-government sehingga dapat terwujud transformasi e-government yang tepat guna dan tepat sasaran dan selalu dapat beradaptasi dengan perkembangan zaman, dalam menguatkan tata kelola layanan publik berbasis pengetahuan yang lebih holistik membangun negara dan bangsa.

\section{DAFTAR PUSTAKA}

Akpinar, T. A., \& Akdemir, A. (2011). Intellectual Capital. Turkey: Kocaeli University.

Alwis, D. (2004). The Role of Intellectual Capital in Organisational Value Creation: an Application of a Theoretical Model to Two Case Studies. United Kingdom: Brunel University.

Artinah, B. (2011). Pengaruh Intellectual Capital Terhadap Profitabilitas (Studi Empiris pada Perusahaan Perbankan). Socioscientia Jurnal Ilmu-Ilmu Sosial Vol 3 No 1, 53.

Boisot, M. (2002). The Strategic Management of Intellectual Capital and Organizational Knowledge. (C. W. Choo, \& N. Bontis, Penyunt.) New York: Oxford University Press.

Bontis, N. (1999). Managing Organizational Knowledge by Diagnosing Intellectual Capital Framing and Advancing The State of The Field. International Journal of Technology Management Vol 18 No 5/6/7/8, 433-62.

Bontis, N. (2000, October 11). Assesing Knowledge Assets: A Review of The Models Used to Measure Intellectual Capital. Diambil kembali dari Assesing Knowledge Assets: A Review of The Models Used to Measure Intellectual Capital: http://cieseerx.ist.psu.edu/viewdoc/download? doi=10.1.1.112.8365\&rep=rep1\&type $=$ pdf

Budihardjo, A. (2017). Knowledge Management: Efektif Berinovasi Meraih Sukses. Jakarta: Prasetya Mulya Publishing.

Caddy, I. (2007). IntellectualCapital and Quality Management: Strange Bedfellows or New $\begin{array}{lllllllll}I & n & s & i & g & h & t & s\end{array}$ http://www.aair.org.au/app/webroot/media/pdf /AAIR\%20Fora/Forum2007/Caddy.pdf

Chang, A., \& Tseng, C.-N. (2005). Building Customer Capital Through Relationship Marketing Activities: The case of Taiwanese Multilevel Marketing Companies. Journal of Intellectual Capital.

Christensen, C. M. (1997). The Innovator's Dilemma: When New Technologies Cause Great Firms to Fail. Boston: Harvard Business School Press.

Clark, T. R. (2008). Epic Change: How To Lead Change in The Global Age. San Fransisco: John Wiley \& Sons, Inc.

Clarkson, M. B. (1995). A Stakeholder Framework for Analyzing and Evaluating Corporate Social Performance. The Academy of Management Review, 92-117.

Davenport, T. H., \& Prusak, L. (1998). Working Knowledge: How Organizations Manage What They Know. Boston: Harvard Business School Press.

Europian Commision. (2000). Making a Reality of The Europian Research Area: Guidelines for EU Research Activities (2002-2006). Brussel: $\operatorname{COM}(2000) 612$ Final.

Flak, L. S., \& Rose, J. (2005). Stakeholder Governance: Adapting Stakeholder Theory to E-Government. Communications of the Association for Information Systems, 662-664.

Fredman, J. P. (2000). Dictionary of Business Terms. New York: Barron's Educational Series, Inc.

Frooman, J. (1999). Stakeholder Influence Strategies. Academy of Management Review, 191-205.

Geus, A. D. (1997). The Living Company. Boston: Harvard Bussiness School Press.

Göran, R. (2005). Managing Intellectual Capital in Practice. Oxford: Elsivier Ltd.

Guah, M. W. (2007). GlobalE-Government: Theory, Applications, and Benchmarking. (L. al-Hakim, Penyunt.) Australia: Idea Group Publishing.

Guthrie, J., \& Petty, R. M. (2000). Intellectual Capital: Australian Annual Reporting Practices. Journal of Intellectual Capital, I, 241-251. 
Harimurti, R. M. (2010). Dinamika Pengelolaan Teknologi Informasi Pemerintaha dan Model Connected Government Sebagai Solusi. Jurnal Penelitian Teknologi Informasi dan $\begin{array}{llllllllll}K & o & m & u & n & i & k & a & s & i\end{array}$. https://media.neliti.com/media/publications/2 33772-dinamika-pengelolaan-teknologiinformasi-2f76bc43.pdf

Harrison, S., \& Sullivan, P. H. (2000). Profiting form Intellectual Capital: Learning from Leading Companies. Journal of Intellectual Capital Vol. 1 No. 1, 33-46.

Holland, J., \& Holland, J. (2010). Intellectual Capital and Technological Innovation: Knowledge-Based Theory and Practice. New York: Hershey.

Horibe, F. D. (1999). Managing Knowledge Workers: New Skills and Attitudes to Unlock The Intellectual Capital in Your Organization. Canada: John Wiley\&Sons Canada Limited.

Ingham, J. (2007). Strategic Human Capital Management: Creating Value Through People. USA: Elsevier Ltd.

Intellectual Capital and Corporate Value in Emerging Economy: Empirical Study of Taiwanese Manufacturers. (2005). R\&D Management Vol. 35 No. 2, 187-205.

Kadir, A., \& Triwahyuni, T. (2003). Pengendalian Teknologi Informasi. Yogyakarta: Andi.

Kelly, A. (2004). The Intellectual Capital of School: Measuring and Managing Knowledge, Responsibility and Reward: Lesson from The Commercial Sector. United Kingdom: Kluwer Academic Publishers.

Komite Standar Akuntansi Pemerintahan. (2011). Buletin Teknis Nomor 11 tentang Akuntansi Aset Tidak Berwujud. Diambil kembali dari http://www.ksap.org/Buletin/Bultek\%20SAP $\% 20$ Nomor $\% 2011 \% 20$ ATB.pdf

Lev, B. (2001). Intangible: Management, Measurement, and Reporting. Washington: The Brooking Institution.

Lynch, K. (2000). Education for Citizenship: The Need for a Major Intervention in Social and Political Education in Ireland. CSPE Conference. Bunratty Co.

Marr, B., \& Gray, D. (2006). Strategic Performance Management: Leveraging and Measuring Your Intangible Value Drivers. USA: Elsevier Ltd.

Masyhur, F. (2017). Penelitian e-Government di Indonesia: Studi Literatur Sistematis dari Perspektif Dimensi Pemeringkatan eGovernment Indonesia (PeGI). IPTEK-KOM, 51-62.
Mouritsen, J., \& et al. (2003). Intellectual Capital Statements: The New Guidelines. Denmark: Danish Ministry of Science Technology and Innovation.

Mulder, M., \& Winterton, J. (2017). CompetenceBased Vovational and Professional Education: Bridging The Worlds of Work and Education. (M. Mulder, Penyunt.) Switzerland: Springer Nature.

Munandar, I., Pratama, A. A., \& Satria, D. (2017). Menilai Penerapan e-government di Kemeterian/Lembaga Negara Republik Indonesia Menggunakan Framework PeGI. Balai Pendidikan dan Pelatihan Tambang Bawah Tanah.

Nugraha, J. T. (2018). E-Government dan Pelayanan Publik (Studi Tentang Elemen Sukses Pengembangan E-Government di Pemerintah Kabupaten Sleman). Jurnal Komunikasi dan Kajian Media, 32-42.

Pearce, J. A., \& Robinson, R. B. (2000). Strategic Management: Formulation, Implementation, and Control. University of California: Irwin/McGraw-HIll.

Petty, R. M., \& et al. (2009). Intellectual Capital and Valuation: Challenges in The Voluntary Disclosure of Value Drivers. Journal of Finance and Accountancy.

Roos, J., Roos, G., Dragonetti, N., \& Edvinsson, L. (1997). Intellectual Capital: Navigating Te New Business Landscape. London: Macmillan Press LTD.

Ross, G., \& et al. (2001). Intellectual Capital Analysis as A Strategic Tool. Startegy \& Leadership. 29(4)., 21-26.

Satriya, E. (2006). Pentingnya Revitalisasi egovernment di Indonesia. Prosiding Konferensi NAsional Teknologi Informasi \& Komunikasi Untuk Indonesia. Bandung: Institut Teknologi Bandung.

Senge, P. M. (1990). The Fifth Discipline: The Art and Practice of The Learning Organization. New York: Doubleday.

Sohrabi, B., \& et al. (2010). Intellectual CApital and Technological Innovation: KnowledgeBased Theory and Practice. New York: Hershey.

Sveiby, \& Erick, K. (1996). The New Organizational Wealth: Managing and Measuring Knowledge-Based Assets. San Fransisco: Berret-Koehler Publishers, Inc.

The World Bank. (2002). The E-Government Handbook For Developing Countries. (M. A. Khalil, B. D. Lanvin, \& V. Chaudhry, Penyunt.) Center For Democracy Technology. 
Tseng, C., \& Goo, Y. J. (2005). Intellectual Capital and Corporate Value in Emerging Economy Empirical Study of Taiwanese Manufacturers. R\&D Management Vol 35 No 2, 187-205.

Utomo, T. W. (2016, November 5). PNS Harus Menguasai Teknologi Informasi. Diambil ke mbali dari Berita Satu: https://www.beritasatu.com/nasional/397321pns-harus-menguasai-teknologi-informasi

World Bank, T. (2002). The e-government Handbook for Developing Countries. Center For Democracy Technology.

Yodmongkon, P., \& Chakpitak, N. (2009). Applying Intellectual Capital Process Model for CReating a Defensive Protection Systemto Local Traditional Knowledge:The Case of Mea-Hiya Community. Electronic Journal of Knowledge Management, 7(4), 519.

Yohana, N., \& Yazid, T. P. (2014). Pemanfaatan Website Pemerintah Kota Pekanbaru dalam Mewujudkan Good Governance. Masyarakat Telematika dan Informasi, 153-168.
Yunita, N. P., \& Aprianto, R. D. (2018). Kondisi Terkini Perkembangan Pelaksanaan EGovernment di Indonesia: Analisis Website. Seminar Nasional Teknologi Informasi dan Komunikasi. Yogyakarta: Universitas Atmajaya.

Zyl, C. V. (2005). Structural Capital Management Creates Sustainable Competitiveness and Prolonged First-Mover Advantage. Acta Commercii: Intellectual Capital Mangement Series.

Zyl, C. V. (2005). Structural Capital Management Creates SustainableCompetitiveness and Prolonged First-MOver Advantages. Acta Commercii: Intellectual Capital Management Series. 